\title{
Effects of non-native riparian plants in riparian and fluvial ecosystems: a review for the lberian Peninsula
}

\author{
Pilar Castro-Díez* and Álvaro Alonso
}

Departamento de Ciencias de la Vida, Facultad de Ciencias, Universidad de Alcalá, Ctra. Madrid-Barcelona s/n, E28805 Alcalá de Henares, Madrid, España.

* Corresponding author: mpilar.castro@uah.es

Received: 31/10/16

Accepted: 10/03/17

\begin{abstract}
Effects of non-native riparian plants in riparian and fluvial ecosystems: a review for the Iberian Peninsula

Riparian zones are among the natural habitats more prone to be invaded by exotic plants. In this study we review the causes and consequences of these invasions on fluvial and riparian ecosystems, as well as the effects described for the Iberian Peninsula so far. Riparian zones receive a high propagule pressure of exotic plants, their abiotic conditions are benign for plant life, and their biotic resistance from native vegetation is released by natural (floods) and anthropic (hydrological changes) disturbances. The convergence of these factors explains the high invasion rate of riparian zones. An eventual replacement of native by nonnative vegetation might alter the fire regime, the depth of the water table, nutrient cycles and organic matter processing, soil properties, communities of detritivore invertebrates and vertebrates dwelling in rivers and riparian zones. In the Iberian Peninsula we found that the effects of non-native riparian plants were more often negative (e.g. alteration of the structure and activity of microbial communities) than neutral (e.g. similar decomposition rate between native and non-native litter), and rarely positive for primary production (e.g. faster litter decomposition). Our review also highlights a strong bias in the selection of target non-native species (mostly Eucalyptus globulus, Ailanthus altissima and Robinia pseudoacacia) and in the studied effects (mostly litter decomposition and structure and activity of microbial communities). Therefore, a reliable evaluation of the effects of non-native plants in Iberian riparian ecosystems requires extending the number of studied species and of response variables.
\end{abstract}

Key words: Biological invasions, detritivores macroinvertebrates, fire, hypotheses, invasibility, litter decomposition, microbial communities, nutrient cycle, water table depth.

\section{RESUMEN}

\section{Efectos de las plantas exóticas de riberas en ecosistemas de ríos y riberas: revisión para la Península Ibérica}

Las riberas se encuentran entre los hábitats naturales más vulnerables a ser invadidos por plantas exóticas. En este estudio se hace una revisión sobre las causas y consecuencias de estas invasiones en los ecosistemas, así como de los efectos que se han descrito en la Península Ibérica. En las riberas existe una elevada presión de propágulos exóticos, las condiciones abióticas son benignas para las plantas, la resistencia biótica de la vegetación nativa se ve relajada por las frecuentes perturbaciones y por los cambios hidrológicos causados por el hombre. La confluencia de todos estos factores explica la elevada tasa de invasión de estos ambientes. La sustitución de vegetación nativa por exótica puede generar cambios en el régimen de incendios, en el nivel freático, en los ciclos de nutrientes y procesamiento de la materia orgánica, en las propiedades del suelo, en las comunidades de invertebrados que procesan la materia orgánica y en las comunidades de vertebrados que habitan en los ríos y en las riberas. En el caso de la Península Ibérica encontramos que las plantas exóticas de ribera causan más frecuentemente efectos negativos (por ej. alteraciones de la estructura y actividad de las comunidades microbianas), seguido de efectos neutros (por ej. en la tasa de descomposición de la hojarasca) y muy pocos efectos positivos para la producción primaria (por ej. aceleración de descomposición de la hojarasca). Sin embargo, se aprecia un notable sesgo en cuanto a las especies estudiadas (mayoritariamente Eucalyptus globulus, Ailanthus altissima y Robinia pseudoacacia) y en cuanto a los efectos estudiados (principalmente descomposición de hojarasca y actividad y estructura de comunidades microbianas). Por tanto, una adecuada evaluación de los efectos de las plantas exóticas de riberas ibéricas requiere ampliar el número de especies consideradas y el tipo de variables respuesta. 
Palabras clave: Ciclo de nutrientes, comunidades microbianas, descomposición de hojarasca, hipótesis, incendios, invasibilidad, invasiones biológicas, macro-invertebrados detritívoros, nivel freático.

\section{INTRODUCTION}

Riparian zones are those extending from the river margins to the limits of the area wherein community structure is influenced by flooding (Goudie, 2004). This strip of land is considered as the transition or ecotone between the aquatic ecosystem of the river and the terrestrial ecosystem of the valley (Naiman \& Decamps, 1997). The proximity to the river provides riparian zones with year-round soil moisture due to a permanent water table. Additionally, sediments transported by rivers are deposited on river banks, forming fertile soils (Goudie, 2004). This high nutrient and water availability confer a higher potential primary productivity to riparian zones compared to adjacent terrestrial areas, but the proximity to the river also implies a high risk of flood disturbance. The confluence of high productivity and periodical disturbances contributes to the high biodiversity which characterizes well-preserved riparian forests, and explains their ability to provide multiple services (Vidal-Abarca Gutierrez \& Alonso, 2013). For instance, riparian forests mitigate the undesired effects of river floods by laminating high discharges, reducing water energy and soil erosion, and promoting deposition of sediments. In addition, riparian forests reduce river eutrophication by absorbing part of the nutrient load carried by runoff from adjacent fields, and by casting shade on the water column (Karr \& Schlosser, 1978; Naiman \& Decamps, 1997; Burrell et al., 2014). The shaded, humid and temperature-buffered environment created under the riparian forest canopy, along with the availability of water, offer recreational opportunities to local populations (Briggs, 1996; Vidal-Abarca Gutierrez \& Alonso, 2013).

In spite of the variety of ecosystems services provided by well-preserved riparian forests, most riparian zones in highly populated regions have been deforested and/or deeply degraded. Since the ancient times, humans have competed with vegetation for occupying the fertile riparian soils, frequently reducing the riparian forest to a narrow hedge in the waterside (Fig. 1). Another important cause of riparian forest degradation is the alteration of water fluxes and channels, either by extracting water from rivers, by altering the flooding regime through the construction of dams, or by altering the shape of the river channel to prevent ordinary floods and to gain arable land for crops (Naiman \& Decamps, 1997; VidalAbarca Gutierrez \& Alonso, 2013). A more recent threat to the integrity and functionality of riparian forests is the growing rate of invasion by non-native plant species which, as explained below, is an undesired consequence of the riparian zone properties, often exacerbated by human management. Plant invasions may reduce the diversity of the native ecosystems by displacing species and displaying a high local dominance. Changes in the vegetation composition and structure may alter key ecosystem processes involving water and nutrient cycles. Finally, the effects of invaders may propagate across the food webs altering the structure and functioning of fluvial and riparian animal communities.

The present study aims at reviewing and synthesizing the current knowledge on the causes and ecological consequences of non-native plants invading riparian zones. Specifically, in this work we present: 1) a comprehensive review of the causes explaining the vulnerability of riparian zones to invasion by exotic plants, by summarizing the multiple hypotheses available in the literature; 2) a thorough synthesis of the impacts that non-native riparian plants may cause to riparian and fluvial ecosystems, and 3) an updated review of the available knowledge on the effects that non-native plants cause in in riparian and fluvial ecosystems of the Iberian Peninsula. 


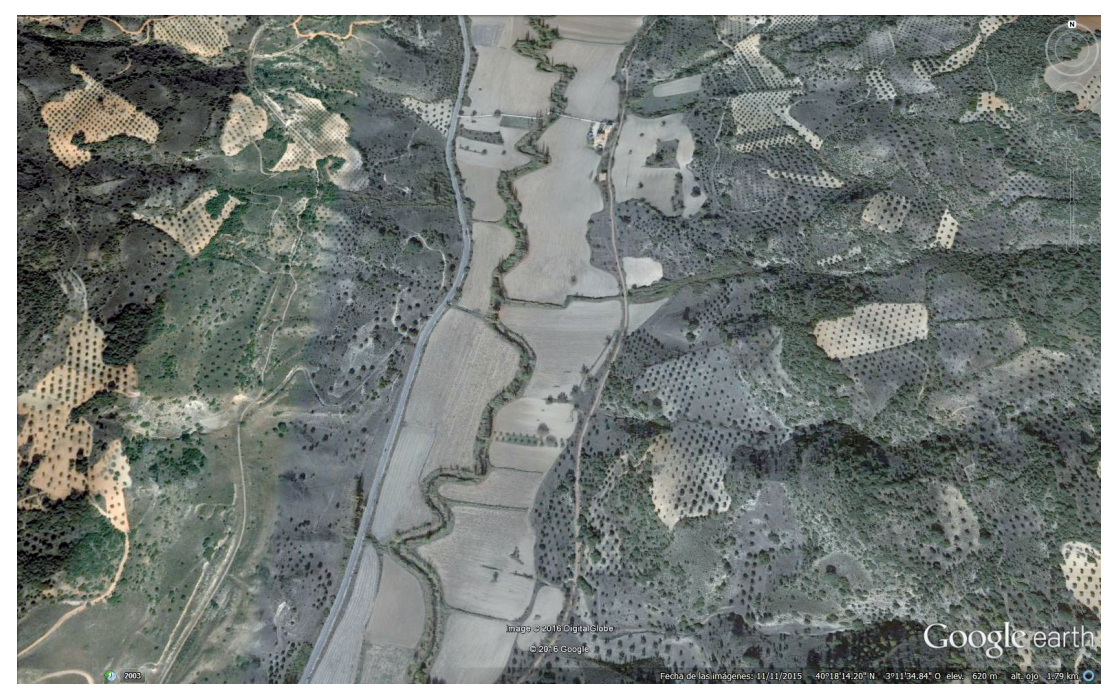

Figure 1. Aerial photograph of the Tajuña River (Orusco, Madrid), where the riparian zone has been occupied by crops and the riparian forest has been narrowed to a single row of trees (Image from Google Earth). Fotografía aérea del río Tajuña (Orusco, Madrid), donde la llanura aluvial ha sido ocupada por cultivos y el bosque de ribera ha sido reducido a una fila de árboles (Imagen de Google Earth).

\section{INVASIVE SPECIES}

Invasive species are non-native species which have been able to overcome geographical barriers (i.e. non-native, alien or exotic), establish self-sustaining populations in the new region -overcoming local abiotic and biotic filters- (i.e. naturalized), and expand rapidly from the initial introduction point (i.e. invader, Richardson et al., 2000). This definition implies that the invasion is a staged process, where a series of barriers or ecological filters should be successively passed by the invasive species. A consequence of this successive filtering is that the number of species reaching each stage diminishes, so that, among all the non-native species able to reach a new region only a very small proportion finally becomes successful invaders (Williamson \& Fitter, 1996; Levine et al., 2004; Catford et al., 2009).

Invasive species have the potential to alter the structure and functioning of the recipient community, either by causing the local extinction of native species and/or by adding novel functional traits to the community (Castro-Díez et al., 2016). A decline on the local diversity is the most often reported impact of plant invasions
(Levine et al., 2003; Vilà et al., 2011; Pyšek et al., 2012; Vilà et al., 2015). However, changes in species composition also modify the phylogenetic and functional structure of the community (Cadotte et al., 2011; Lapiedra et al., 2015; Castro-Díez et al., 2016), which in turn may alter ecological processes, such as the nutrient cycle, the water cycle or the fire regime (Le Maitre $e t$ al., 1996; Levine et al., 2003; Ehrenfeld, 2010; Corbin \& D’Antonio, 2011; Castro-Díez et al., 2014). Consequently, in the last decades there has been a growing concern on understanding how biological invasions affect biodiversity and the ability of ecosystems to supply multiple services (Charles \& Dukes, 2007; Vilà et al., 2010; Constan-Nava et al., 2015; Hulme et al., 2017), and on developing protocols for managing biological invasions (Simberloff, 2009; Hulme, 2012; Leung et al., 2012; Leung et al., 2014).

\section{VULNERABILITY OF RIPARIAN ZONES TO PLANT INVASIONS}

Riparian zones are among the natural habitats exhibiting a higher proportion of invasive plants, 
particularly in the Mediterranean region (Hood \& Naiman, 2000; Vilà et al., 2001; Chytrý et al., 2008). Understanding what is behind this pattern requires understanding the reasons that explain invasive success.

Multiple hypotheses have been put forward to explain the success of invaders. Some of them emphasize that certain traits confer invasive potential on species, such as the "ideal weed" (Baker, 1965; Rejmánek \& Richardson, 1996) or the "novel weapon hypothesis" (Callaway \& Ridenour, 2004). Other hypotheses focus on the opportunities offered by recipient communities to recently arrived species, such as the "empty niche" (Hierro et al., 2005) or the "biotic resistance" (Levine et al., 2004; Alpert, 2006). Certain hypotheses stress the importance of the interactions between the invader and the species in the recipient community to enhance or hamper the invasion process, e.g. the "enemy release" (Keane \& Crawley, 2002) or the "missed mutualisms" (Alpert, 2006). Other hypotheses emphasize that the abiotic properties and the resource availability of the recipient ecosystem determine the chances of non-native species to become invaders, e.g. the "habitat filtering" (Darwin, 1859; Melbourne et al., 2007), the "fluctuating resource" (Davis et al., 2000) or the "environmental heterogeneity" (Alpert, 2006). Finally, other hypotheses focus on the introduction effort as a major driver of biological invasions, such as the "propagule pressure" (Lonsdale, 1999; Colautti et al., 2006) or the "global competition hypothesis" (Colautti et al., 2006).

Catford et al. (2009) synthesized these multiple hypotheses in three major conditions which should converge to allow a successful invasion: 1) The propagule pressure should be large enough to overcome dispersal and geographical constraints. 2) The abiotic properties of the recipient ecosystems should be hospitable enough to allow survival and reproduction of the novel species. 3) The biotic interactions between the novel and the resident species should promote invasion, or at least should not constrain it.

The particular conditions of riparian zones offer good chances for the convergence of the three above-mentioned conditions for success- ful invasions. Firstly, rivers and riparian zones have been described as effective corridors for exotic propagules (Dyderski et al., 2015). On the one hand rivers may transport large quantities of seeds and other propagules which are deposited downstream in the river bank (Tabacchi et al., 2005; Kowarik \& Saumel, 2008; Cabra-Rivas et $a l ., 2014)$. Many of these propagules come from the exotic species growing in human-created habitats which frequently occur in the proximity of the rivers, such as crops, urban gardens, roads, etc. (Tickner et al., 2001; Dyderski et al., 2015).

Secondly, the climatic limitations for plant growth tend to be buffered by the proximity to the river. This is especially relevant under continental Mediterranean conditions, where both summer water stress and winter frosts limit plant growth (Mitrakos, 1980). Under these limiting circumstances, only a few exotic species - those pre-adapted or coming from other similar environments- have good chances of establishment. However, the presence of a permanent water table in riparian zones mitigates the summer stress and the close canopy of riparian forests buffers extreme temperatures (Naiman \& Decamps, 1997). In addition, the low soil fertility which prevents exotic establishment in many regions is also compensated by the continuous supply of organic sediments deposited in the river banks after floodwater receding. All these hospitable conditions give good chances of establishment to novel species.

An additional abiotic factor contributing to explain the high invasibility of many riparian zones is the change of water regimes caused by human management. Man has built dams, created water reservoirs, derived large quantities of river water for irrigation, industry or urban supply, and many river channels have been rectified and constrained by levees to gain arable surface protected from ordinary floods (Naiman \& Decamps, 1997; Aguiar et al., 2001; Vidal-Abarca Gutierrez \& Alonso, 2013; Zarfl et al., 2015). All these alterations decrease the magnitude and frequency of floods, reduce the transfer of sediment through channel networks, stabilize channels, increase water speed and its erosion power, decline water tables and sometimes promote salinization (Mer- 
ritt \& Poff, 2010; Catford et al., 2011; Rundel et al., 2014; Tombolini et al., 2014; Lobera et al., 2015). These changes can facilitate plant invasion by providing conditions that benefit nonnative species, or by reducing competition from native species unsuited to the modified conditions (Aguiar et al., 2001; Catford et al., 2011; Cooper et al., 2013; Rundel et al., 2014; Liendo et al., 2015). A good example of this is the dramatic invasion of Southwestern USA riparian zones by several species of saltcedar (Tamarix spp), a shrub of Euroasiatic origin. Although saltcedar was introduced at the end of the $19^{\text {th }}$ century, its greatest expansion occurred by the 1960s, coinciding with the construction and operation of dams. The reduction of floods, the water table decline and the salinization that followed, appear to have favored saltcedar over other native species (Glenn \& Nagler, 2005; Merritt \& Poff, 2010).

Thirdly, biotic interactions in riparian zones should - at least - not hamper the establishment of non-native plants. Well-preserved riparian forests developed under natural water regimes may appear to exert a strong biotic resistance to the establishment of new species. However, the episodic floods open gaps that are colonized by any pioneer species, either native or non-native, able to send propagules to the gap. Therefore these communities are a mosaic of patches at different successional stages which offer chances of establishment to a wide range of life strategies (Naiman \& Decamps, 1997; Geilen et al., 2004). Riparian zones affected by flow regulation are even more favorable for non-native invasion because the decline of the native populations unsuited to the modified conditions reduces the biotic resistance (Catford et al., 2012). Besides, the modified conditions may offer good chances of establishment to non-native species pre-adapted to the new conditions, as mentioned above (Rundel et al., 2014).

\section{IMPACTS OF PLANT INVASIONS ON FLUVIAL AND RIPARIAN ECOSYSTEMS}

Biological invasions alter not only the structure but also the function of recipient ecosystems. In the case of plant invasions of riparian forests or adjacent catchments, different types of impacts on the fluvial or riparian ecosystems have been described, such as changes in fluvial geomorphic processes and the fire regime, alteration of water and soil properties, as well as effects on other organisms through the trophic web. In the following paragraphs several examples of these impacts are described.

\section{Changes in fluvial geomorphic processes}

Riparian vegetation is known to be a relevant factor regulating fluvial geomorphic processes (Osterkamp \& Hupp, 2010). Therefore, vegetation changes driven by plant invasions may also alter geomorphic processes. A well-known example is that of the saltcedar invasion in riparian areas of southwestern USA. Saltcedar develops dense and extensive thickets of roots, which makes it valuable for erosion control (Zavaleta, 2000). However, this property also enhances the trap and stabilization of sediments, enlarging islands and banks and narrowing river channels (Blackburn et al., 1982; Manners et al., 2014). Narrowed channels are less effective in evacuating high waters, worsening the frequency and severity of flood damage (Graf, 1978; Zavaleta, 2000). A similar example can be found in the giant reed (Arundo donax), a worldwide invasive species native to South Asia. The giant reed is a very tall and robust perennial grass with large, spreading clumps of thick culms up to $6 \mathrm{~m}$ tall. The profuse growth of its lignified rhizomes contributes to trap sediments and to narrow stream channels, becoming also in a problem for flood control (Lowe et al., 2000; Sanz Elorza et al., 2004; Dana Sánchez et al., 2005).

\section{Alteration of fire regime}

In Mediterranean-type ecosystems riparian forests are less prone to fire than other vegetation types, due to their high soil and plant moisture and to the fast decomposition of dead plant tissues. However, when native deciduous trees are replaced by exotic trees with less tissue water content and/or slower litter decomposition, the 
increased fuel load may increase the fire risk during the arid period (Levine et al., 2003). A good example of this is the replacement of the native riparian forests by Eucalyptus globulus plantations in Portugal (Ferreira et al., 2016). This species generates a thick soil layer of leaf litter and bark (Fig. 2) with extremely slow decomposition (Castro-Díez et al., 2012) which easily burns when dried. Riparian forests of the Colorado River (USA) dominated by Tamarix spread fire and resprout faster after fires than non-invaded forests, leading to a feedback between the invader and fire (Nagler et al., 2005). Forest fires leave behind unprotected soils easily eroded by floods (Shakesby, 2011). The loss of the canopy and the erosion of soils result in a drastic loss of organic matter and nutrients, part of which ends up in the water stream contributing to eutrophication (Emelko et al., 2016).

\section{Changes of water use}

Invasive plant species may differ from the native vegetation in their water-use strategy. A well-known case study is that of the Australian Acacias introduced by Europeans in the Cape Region of South Africa -a naturally treeless area- for timber supply. Among other impacts, these species take up larger quantities of water than the native vegetation and dramatically reduce the water yield from invaded catchments, even threatening the urban water supply (Le Maitre et al., 1996). Similarly, several species of Prosopis introduced in arid regions of South Africa possess deep roots which make them particularly successful in deep alluvial soils (Richardson \& van Wilgen, 2004). The benefits provided by the species in terms of fodder production are counterbalanced by the depletion of the aquifers that represent an important water supply for local populations (Shackleton et al., 2015). Finally, the invasion of Tamarix spp. in riversides of the Southwest of North America may decrease the water table due to their high evapotranspiration rates (Di Tomaso, 1998; Zavaleta, 2000).

\section{Changes in soil properties}

When plants invading riparian forests differ from natives in nutrient use strategy or in the quality and/or quantity of the produced litter, the processing of organic matter and the soil properties may be altered (Castro-Díez et al., 2009; Menendez et al., 2013; Medina-Villar et al., 2015; Ferreira et al., 2016). For instance, in a central Spain riparian forest, soils from patches invaded

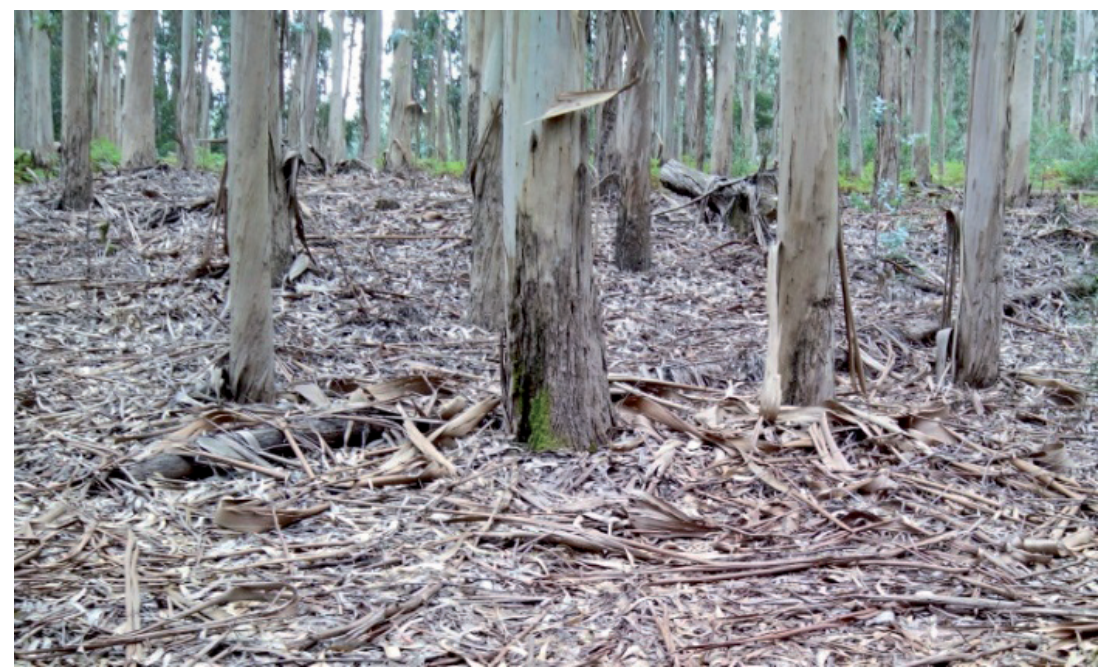

Figure 2. Thick layer of litter (bark peelings and leaves) accumulated under a Eucalyptus globulus plantation in Cíes Islands (Galicia, Northwestern Spain). Photo: P. Castro-Díez. Gruesa capa de hojarasca (restos de cortezas y hojas) acumulados bajo el dosel de una plantación de Eucalyptus globulus en las Islas Cíes (Galicia, noroeste de España). Foto: P. Castro-Díez. 
by Robinia pseudoacacia (a N-fixing legume) showed larger amount of inorganic $\mathrm{N}$ than non-invaded controls (Medina-Villar et al., 2016). Gutiérrez-López et al. (2014) reported differences in physical-chemical soil properties between patches invaded by Ailanthus altissima and nearby non-invaded patches. Leaves of invasive saltcedars in the Colorado River (USA) excrete salts that are deposited on the soil surface, increasing soil salinity (Merritt \& Shafroth, 2012).

\section{Alteration of populations and communities of other organisms}

Changes in riparian soil properties caused by plant invasions have been associated to changes in the composition of the soil arthropod community (Gutiérrez-López et al., 2014; MacedaVeiga et al., 2016). Similarly, aquatic communities feeding on litter from the riparian forest may be altered by the input of exotic litter (Martinez et al., 2013; Correa-Araneda et al., 2015; Ferreira et al., 2015). For instance Medina-Villar et al. (2015) found lower colonization of exotic leaf litter by aquatic fungi and bacteria, which makes litter less palatable for macroinvertebrates. Alterations to aquatic macroinvertebrate communities may propagate up through the food web and affect the fish that feed on them (Maceda-Veiga et al., 2016). More direct impacts of plant invasions may be found in those animals who find shelter and food in the riparian vegetation. For instance, Portuguese riparian forests replaced by eucalypt plantations presented lower fluvial habitat quality for native fish, which contributes to a higher abundance of exotic fish (Oliveira et al., 2016). In African mesic savannas the invasion of riparian areas by the exotic shrub Chromoleana odorata increases shading on riverbanks, which reduces temperature of soils where Nile crocodiles dig nests for egg deposition, leading to altered sex ratios (Leslie \& Spotila, 2001). Riparian corridors of Southeastern USA invaded by Tamarix spp. provide poorer food and habitat for many resident and migrating birds, due to the small size of their seeds and the poor shade cast by their canopies (Hunter et al., 1988; Shafroth et al., 2005).

\section{EFFECTS OF NON-NATIVE PLANTS IN RIVERS AND RIPARIAN ZONES OF THE IBERIAN PENINSULA}

We performed an updated literature review on the ecological effects that non-native plants (either invasive or planted) have in rivers and riparian zones of the Iberian Peninsula. In October 2016 we searched published papers on Web of Science, with no restriction of date, using the following key-words: (exotic or non-native or invasive) and (plant or tree) and (riparian or floodplain) and (Spain or Portugal or Iberian Peninsula) and ((stream or river) or (macroinvertebrate or fish or amphibians) or (leaf litter or breakdown or microbial or decomposition)). Valid studies were those comparing any variable related with the structure and function of the riparian and fluvial ecosystems between sites/treatments dominated by non-native plants and control sites/treatments with native vegetation. Results are summarized in Table 1, where effects are sorted primarily by the type of effect and secondarily by the non-native species.

To gain insight on the representativeness of the available information, we compiled a list of non-native species present in riparian zones of the Iberian Peninsula. For Spain we used a national (Sanz Elorza et al., 2004) and three regional (Dana Sánchez et al., 2005; Campos \& Herrera, 2009; Guerrero-Campo \& Jarne Bretones, 2014) catalogues of exotic invasive plants, and also checked whether the species were included in the official Catalogue of Invasive Species in Spain (Real Decreto 630/2013). In the case of Portugal we used the list of exotic plant species present in continental Portugal (Almeida \& Freitas, 2006; Almeida \& Freitas, 2012), downloaded from www.invasoras.pt in January 2017.

The two most studied variables used to describe the effects of non-native riparian plants were related to the processing of leaf litter (mostly litter decomposition rate, either in water or in soil), and structure and activity of microbial communities (both in soil and in water), with 10 and eight case studies respectively. Less information was found on the effects on invertebrate communities (six case studies) and soil prop- 
Table 1. Summary of the paper review assessing effects that riparian non-native plants (planted or invasive) have on fluvial and riparian ecosystems. Studies were searched in Web of Science for the Iberian Peninsula, with no limitation of publication date. Most studies compared any ecosystem property between a riparian zone dominated by a non-native plant species and a control system dominated by native species. Data are primarily sorted by type of effect (grey rows) and secondarily by the non-native species. Resumen de la revisión de artículos que evalúan los efectos de plantas exóticas de ribera (plantadas o invasoras) en ecosistemas fluviales y ribereños. Los estudios se buscaron en Web of Science para la Península Ibérica, sin restricción del año de publicación. La mayoría de los estudios comparan alguna propiedad ecosistémica entre un río o llanura aluvial dominado por una planta exótica y un sistema control dominado por especies nativas. Los datos están ordenados en primer lugar por tipo de impacto (filas grises) y en segundo lugar por especie exótica.

\begin{tabular}{|c|c|c|c|c|c|}
\hline Non-native species & Description of the effect & $\begin{array}{l}\text { Effect } \\
\text { type }\end{array}$ & $\begin{array}{l}\text { Type of } \\
\text { ecosystem }\end{array}$ & Location & Reference \\
\hline & Effects on soil properties & & & & \\
\hline Ailanthus altissima & $\begin{array}{l}\text { Decreased total soil } \mathrm{N} \text {, soil ammonia and } \\
\text { soil organic matter }\end{array}$ & - & Terrestrial & Central Spain & (Medina-Villar et al., 2016) \\
\hline $\begin{array}{l}\text { Ailanthus altissima } \\
\text { \& Robinia } \\
\text { pseudoacacia }\end{array}$ & No effects on soil mineral $\mathrm{N}$ availability & 0 & Terrestrial & Central Spain & (Castro-Díez et al., 2009) \\
\hline $\begin{array}{l}\text { Ailanthus altissima } \\
\& \text { Robinia } \\
\text { pseudoacacia }\end{array}$ & $\begin{array}{l}\text { Similar properties (pH, organic matter, } \mathrm{N} \\
\text { content) were found between soils } \\
\text { incubated with non-native and native leaf } \\
\text { litter }\end{array}$ & 0 & Terrestrial & Central Spain & (Castro-Díez et al., 2012) \\
\hline \multirow{2}{*}{$\begin{array}{l}\text { Robinia } \\
\text { pseudoacacia }\end{array}$} & Increased mineral soil $\mathrm{N}$ & + & Terrestrial & Central Spain & (Medina-Villar et al., 2016) \\
\hline & Effects on processing of organic matter & & & & \\
\hline Ailanthus altissima & $\begin{array}{l}\text { Similar litter decomposition rate than } \\
\text { coexisting natives in a stream }\end{array}$ & 0 & Aquatic & Central Spain & (Medina-Villar et al., 2015) \\
\hline Ailanthus altissima & $\begin{array}{l}\text { Similar litter decomposition rate than } \\
\text { coexisting natives Fraxinus angustifolia } \\
\text { and Ulmus minor in a lentic ecosystem }\end{array}$ & 0 & Aquatic & Central Spain & (Alonso et al., 2010) \\
\hline Ailanthus altissima & $\begin{array}{l}\text { Faster leaf litter decomposition in soils } \\
\text { than a native control }\end{array}$ & + & Terrestrial & Central Spain & (Castro-Díez et al., 2009) \\
\hline $\begin{array}{l}\text { Ailanthus altissima } \\
\text { \& Robinia } \\
\text { pseudoacacia }\end{array}$ & $\begin{array}{l}\text { Similar litter decomposition rates to } \\
\text { coexisting native riparian tree species in } \\
\text { soils }\end{array}$ & 0 & Terrestrial & Central Spain & (Castro-Díez et al., 2012) \\
\hline Eucalyptus globulus & $\begin{array}{l}\text { Decomposition rate of leaf litter of the } \\
\text { native tree Alnus glutinosa was slower in } \\
\text { streams dominated by exotic plantations } \\
\text { of Eucalyptus globulus than that in } \\
\text { streams with native forests }\end{array}$ & - & Aquatic & Portugal & (Ferreira et al., 2015) \\
\hline Eucalyptus globulus & $\begin{array}{l}\text { Decomposition rate of the same litter } \\
\text { was similar in streams bordered by } \\
\text { eucalypts and by native forest }\end{array}$ & 0 & Aquatic & Portugal & (Barlocher \& Graça, 2002) \\
\hline Platanus hybrida & $\begin{array}{l}\text { faster decomposition of native leaf litter } \\
\text { in reaches dominated by the non-native } \\
\text { than in reaches dominated by native trees }\end{array}$ & + & Aquatic & NE Spain & (Menendez et al., 2013) \\
\hline $\begin{array}{l}\text { Robinia } \\
\text { pseudoacacia }\end{array}$ & $\begin{array}{l}\text { Slower litter decomposition rate than } \\
\text { coexisting native litter in a river }\end{array}$ & - & Aquatic & Central Spain & (Medina-Villar et al., 2015) \\
\hline $\begin{array}{l}\text { Robinia } \\
\text { pseudoacacia }\end{array}$ & $\begin{array}{l}\text { Slower litter decomposition rate than the } \\
\text { natives Fraxinus angustifolia and Ulmus } \\
\text { minor in a lentic ecosystem }\end{array}$ & - & Aquatic & Central Spain & (Alonso et al., 2010) \\
\hline $\begin{array}{l}\text { Robinia } \\
\text { pseudoacacia }\end{array}$ & $\begin{array}{l}\text { Slower leaf litter decomposition in soils } \\
\text { than a native control }\end{array}$ & - & Terrestrial & Central Spain & (Castro-Díez et al., 2009) \\
\hline
\end{tabular}




\begin{tabular}{|c|c|c|c|c|c|}
\hline Non-native species & Description of the effect & $\begin{array}{l}\text { Effect } \\
\text { type }\end{array}$ & $\begin{array}{l}\text { Type of } \\
\text { ecosystem }\end{array}$ & Location & Reference \\
\hline & Effects on invertebrate communities & & & & \\
\hline $\begin{array}{l}\text { Acacia dealbata \& } \\
\text { Eucalyptus globulus }\end{array}$ & $\begin{array}{l}\text { No effect on the richness of collembolan } \\
\text { communities in the soil }\end{array}$ & 0 & Terrestrial & Portugal & (Pinto et al., 1997) \\
\hline Ailanthus altissima & $\begin{array}{l}\text { Alteratered structure of soil } \\
\text { microarthropod community }\end{array}$ & - & Terrestrial & Central Spain & (Gutiérrez-López et al., 2014) \\
\hline $\begin{array}{l}\text { Ailanthus altissima } \\
\text { \& Robinia } \\
\text { pseudoacacia }\end{array}$ & $\begin{array}{l}\text { No effect on the structure of the } \\
\text { invertebrate community colonizing the } \\
\text { leaf litter }\end{array}$ & 0 & Aquatic & Central Spain & (Medina-Villar et al., 2015) \\
\hline Eucalyptus globulus & $\begin{array}{l}\text { Reduced abundance of stream } \\
\text { invertebrates }\end{array}$ & - & Aquatic & Portugal & (Ferreira et al., 2015) \\
\hline Eucalyptus globulus & $\begin{array}{l}\text { Reduced growth of the detritivore } \\
\text { caddisfly Calamoceras marsupus in } \\
\text { presence of Eucalyptus leaf litter as } \\
\text { compared to native litter }\end{array}$ & - & Aquatic & Spain & (Correa-Araneda et al., 2015) \\
\hline \multirow[t]{2}{*}{$\begin{array}{l}\text { Pinus radiata \& } \\
\text { Platanus hispanica }\end{array}$} & $\begin{array}{l}\text { Decreased density of total } \\
\text { macroinvertebrates and shredders }\end{array}$ & - & Aquatic & North Spain & (Martinez et al., 2013) \\
\hline & $\begin{array}{l}\text { Effects on microbial communities and } \\
\text { activity }\end{array}$ & & & & \\
\hline Ailanthus altissima & $\begin{array}{l}\text { Decreased net nitrification and total } \\
\text { nitrogen mineralization rates } \\
\text { Altered soil bacterial community }\end{array}$ & - & Terrestrial & Central Spain & (Medina-Villar et al., 2016) \\
\hline $\begin{array}{l}\text { Ailanthus altissima } \\
\text { \& Robinia } \\
\text { pseudoacacia }\end{array}$ & $\begin{array}{l}\text { Decreased fungal biomass in leaf litter } \\
\text { decomposing in the stream }\end{array}$ & - & Aquatic & Spain & (Medina-Villar et al. 2015) \\
\hline $\begin{array}{l}\text { Ailanthus altissima } \\
\text { \& Robinia } \\
\text { pseudoacacia }\end{array}$ & No effects on soil $\mathrm{N}$ mineralization & 0 & Terrestrial & Central Spain & (Castro-Díez et al., 2009) \\
\hline Arundo donax & $\begin{array}{l}\text { Decreased abundance and diversity of } \\
\text { the soil macro-arthropods }\end{array}$ & - & Terrestrial & NE Spain & (Maceda-Veiga et al., 2016) \\
\hline Eucalyptus globulus & $\begin{array}{l}\text { Lower species richness and evenness of } \\
\text { aquatic hyphomycetes }\end{array}$ & - & Aquatic & Portugal & (Ferreira et al., 2015) \\
\hline Eucalyptus globulus & $\begin{array}{l}\text { Little effect on activity and diversity of } \\
\text { aquatic hyphomycete in rivers }\end{array}$ & 0 & Aquatic & North Spain & (Chauvet et al., 1997) \\
\hline Eucalyptus globulus & $\begin{array}{l}\text { Decreased richness and evenness of } \\
\text { aquatic hyphomycetes }\end{array}$ & - & Aquatic & Portugal & (Barlocher \& Graça, 2002) \\
\hline $\begin{array}{l}\text { Robinia } \\
\text { pseudoacacia }\end{array}$ & $\begin{array}{l}\text { Greater phosphomonoesterase activity } \\
\text { and net ammonification rates } \\
\text { No clear effect on soil bacterial } \\
\text { composition }\end{array}$ & $\begin{array}{l}+ \\
0\end{array}$ & Terrestrial & Central Spain & (Medina-Villar et al., 2016) \\
\hline
\end{tabular}

Effects on vertebrate communities

Eucalyptus globulus Decreased fish productivity

Eucalyptus globulus Higher abundance of fish alien species and functional alterations in the fish trophic groups
- Aquatic Iberian Peninsula (Maceda-Veiga, 2013)

- Aquatic Portugal (Oliveira et al., 2016)

trophic 
Table 2. List of non-native plant species invading riparian zones in the Iberian Peninsula. Species are shorted by growth form. Species with an asterisk are those for which there is bibliographic information on their ecological impacts in the Iberian Peninsula (see Table 1). Lista de especies de plantas exóticas que invaden riberas en la Península Ibérica. Las especies están ordenadas según su forma de crecimiento. Las especies con asterisco son aquéllas para las que hemos encontrado información de los impactos ecológicos que causan en la Península Ibérica (ver Tabla 1).

\begin{tabular}{|c|c|c|c|}
\hline Species & Family & Growth form & Refererence $^{(1)}$ \\
\hline Acacia dealbata* & Fabaceae & Tree & $1,2,4,6$ \\
\hline Acer negundo & Aceraceae & Tree & $2,3,4,5,6$ \\
\hline Ailanthus altissima* & Simaroubaceae & Tree & $1,2,3,4,5,6$ \\
\hline Alnus cordata & Betulaceae & Tree & 5 , \\
\hline Elaeagnus angustifolia & Elaeagnaceae & Tree & $2,4,5$ \\
\hline Eucalyptus camaldulensis & Myrtaceae & Tree & $2,4,6$ \\
\hline Eucalyptus globulus* & Myrtaceae & Tree & $2,4,6$ \\
\hline Gleditsia triacanthos & Fabaceae & Tree & $2,4,5,6$ \\
\hline Laburnum anagyroides & Fabaceae & Tree/shrub & 5,6 \\
\hline Platanus hispanica & Platanaceae & Tree & 3,6 \\
\hline Pterocarya stenoptera & Juglandacea & Tree & 3 \\
\hline Robinia pseudoacacia* & Fabaceae & Tree & $2,3,4,5,6$ \\
\hline Buddleja davidii & Buddlejaceae & Shrub & $1,2,3,5,6$ \\
\hline Gomphocarpus fruticosus & Asclepiadaceae & Shrub & $2,4,6$ \\
\hline Lippia filiformis & Verbenaceae & Shrub (procumbent) & 2,5 \\
\hline Ricinus communis & Euphorbiaceae & Shrub & $2,4,6$ \\
\hline Solanum bonariense & Chenopodiaceae & Shrub & 2,4 \\
\hline Vinca difformis & Apocynaceae & Shrub (procumbent) & 2 \\
\hline Araujia sericifera & Apocynaceae & Vine & $1,3,4,5,6$ \\
\hline Fallopia baldschuanica & Polygonaceae & Vine & $1,2,4,5,6$ \\
\hline Ipomoea acuminata & Convolvulaceae & Vine & $2,4,6$ \\
\hline Lonicera japonica & Caprifoliaceae & Vine & $2,3,5,6$ \\
\hline Abutilon theophrasti & Malvaceae & Herb & $2,3,4,6$ \\
\hline Amaranthus hybridus & Amaranthaceae & Herb & $2,3,4,6$ \\
\hline Amaranthus powellii & Amaranthaceae & Herb & $3,4,6$ \\
\hline Artemisia verlotiorum & Asteraceae & Herb & $2,3,5,6$ \\
\hline Arundo donax* & Poaceae & Herb & $2,3,4,6$ \\
\hline Aster novi-belgii & Asteraceae & Herb & 5 \\
\hline Bidens aurea & Asteraceae & Herb & $2,3,4,6$ \\
\hline Bidens frondosa & Asteraceae & Herb & $2,3,4,6$ \\
\hline Bidens pilosa & Asteraceae & Herb & $2,4,6$ \\
\hline Chenopodium ambrosioides & Chenopodiaceae & Herb & 3,6 \\
\hline Cortaderia selloana & Poaceae & Herb & $1,2,3,5,6$ \\
\hline Crocosmia x crocosmiiflora & Iridaceae & Herb & 3,5 \\
\hline Cyperus eragrostis & Cyperaceae & Herb & 3,6 \\
\hline Duchesnea indica & Rosaceae & Herb & 3,6 \\
\hline Echinochloa crus-galli & Poaceae & Herb & 3 \\
\hline Helianthus tuberosus & Asteraceae & Herb & $1,2,3$ \\
\hline Helianthus $x$ laetiflorus & Asteraceae & Herb & 3,6 \\
\hline
\end{tabular}




\begin{tabular}{llll}
\hline Species & Family & Growth form & Refererence $^{(1)}$ \\
\hline Impatiens glandulifera & Balsaminaceae & Herb & 5 \\
Oenothera biennis & Onagraceae & Herb & $2,5,6$ \\
Oenothera glazioviana & Onagraceae & Herb & $2,3,5,6$ \\
Paspalum dilatatum & Poaceae & Herb & $2,3,4,6$ \\
Paspalum paspalodes & Poaceae & Herb & $2,3,4,6$ \\
Phyllostachis spp. & Poaceae & Herb & 5 \\
Reynoutria japonica & Polygonaceae & Herb & $1,2,3,5,6$ \\
Solanum chenopodioides & Chenopodiaceae & Herb & 3,6 \\
Solidago cadandensis & Asteraceae & Herb & 5 \\
Solidago gigantea & Asteraceae & Herb & 5 \\
Tradescantia fluminensis & Commelinaceae & Herb & $1,2,3,5,6$ \\
Veronica persica & Schrophulariaceae & Herb & 3,6 \\
Xanthium strumarium subsp. italicum & Asteraceae & Herb & $2,3,4,6$ \\
\hline
\end{tabular}

(1) 1-Real Decreto 630/2013; 2-(Sanz Elorza et al., 2004); 3-(Campos \& Herrera, 2009); 4-(Dana Sánchez et al., 2005); 5-(Almeida \& Freitas, 2006; Almeida \& Freitas, 2012).

erties (four studies). Finally, the least explored effects were those on vertebrate communities with only two case studies.

The number of non-native riparian plant species whose impact was reported in the literature was quite low. We only found information on four out of the 12 invasive trees, one out of the 30 herbs and none out of the six shrubs and four vines present in Iberian riparian forests (Table 2). Most studies in Portugal focused on Eucalyptus globulus, as plantations of this species have replaced native riparian vegetation of many Portuguese rivers. In Spain, the most studied invaders were Ailanthus altissima and Robinia pseudoacacia, which easily naturalize and invade riparian forests. Fewer studies focused on other non-native species, such as Arundo donax, Acacia dealbata, Pinus radiata and Platanus hybrida, and the last two species were not included in the list of non-native plants invading riparian zones. Although the studied species probably cover the most abundant and conspicuous invaders, our review highlights the scarcity of knowledge on the impacts caused by non-tree invaders in the Iberian Peninsula.

The reported effects of non-native species widely varied across species and studies. Effects on soil properties varied from decreased to in- creased N (Table 1). Litter decomposition was usually slower in $R$. pseudoacacia than in coexisting natives (Table 1). Four out of the six studies on invertebrate communities reported altered structure or reduced abundance of certain groups (Table 1). Effects on microbial communities were mostly negative (altered bacterial or fungal community, decreased microbial activity), and only one study reported a positive effect of $R$. pseudoacacia on the phosphomonoesterase activity (Table 1). Finally, the only two studies on vertebrate communities reported negative effects (decreased fish productivity and increased abundance of non-native fish). Overall, we found 17 negative, 14 neutral and only 4 positive effects of non-native riparian plants on the ecosystems. However, there is a clear need to extend the studies to other non-native species, especially to non-tree species.

\section{CONCLUSIONS}

Riparian zones are highly susceptible to be invaded by non-native plant species, thanks to the confluence of a high propagule pressure, hospitable abiotic conditions for plant growth and reduced biotic resistance due to natural or human- 
caused disturbances. Non-native plants have the potential to alter the structure and functioning of recipient ecosystems by altering the fire regime, by changing water use and nutrient cycles, and by altering the animal communities that find shelter and food in the riparian vegetation. The current knowledge on the effects of non-native riparian plants in Iberian fluvial and riparian ecosystems revealed a higher frequency of negative effects, but also a bias of knowledge, as most studies covered only a few non-native tree species.

\section{ACKNOWLEDGEMENTS}

PCD acknowledges the invitation by the Iberian Limnology Society to present this study in the XVIII Congress and to write this paper. The authors acknowledge the Spanish Ministry of Economy and Competition and the Madrid Community for grants CGL2015-65346-R and REMEDINAL3-M MAE-2719 for supporting their research. The language was reviewed by Dr. Cristina Fernández Aragón.

\section{REFERENCES}

AGUIAR, F.C., M. FERREIRA \& I. MOREIRA. 2001. Exotic and native vegetation establishment following channelization of a Western Iberian river. Regulated rivers: Research \& Management, 17: 509-526. DOI:10.1002/rrr.642.abs

ALMEIDA, J. \& H. FREITAS. 2006. Exotic naturalized flora of continental Portugal - A reassessment. Botanica Complutensis, 30: 117-130.

ALMEIDA, J. \& H. FREITAS. 2012. Exotic flora of continental Portugal - A new assessment. Bocconea, 24: 231-237.

ALONSO, A., N. GONZALEZ-MUNOZ \& P. CASTRO-DÍEZ. 2010. Comparison of leaf decomposition and macroinvertebrate colonization between exotic and native trees in a freshwater ecosystem. Ecological Research, 25: 647-653. DOI:10. 1007/s11284-010-0698-y

ALPERT, P. 2006. The advantages and disadvantages of being introduced. Biological Invasions, 8: 1523-1534. DOI:10.1007/s10530-005-5844-z
BAKER, H.G. 1965. Characteristics and modes of origin of weeds. In: The genetics of colonizing species. Baker, H.G. \& G.L. Stebbins (ed.): 147172. Academic Press, New York.

BARLOCHER, F. \& M.A.S. GRAÇA. 2002. Exotic riparian vegetation lowers fungal diversity but not leaf decomposition in Portuguese streams. Freshwater Biology, 47: 1123-1135. DOI:10.1046/j.13 65-2427.2002.00836.x

BLACKBURN, W.H., R.W. KNIGHT \& J.L. SCHUSTER. 1982. Saltcedar influence on sedimentation in the Brazos River. Journal of Soil and Water Conservation, 37: 298-301.

BRIGGS, M.K. 1996. Riparian Ecosystem Recovery in Arid Lands. University of Arizona Press.

BURRELL, T.K., J.M. O'BRIEN, S.E. GRAHAM, K.S. SIMON, J.S. HARDING \& A.R. MCINTOSH. 2014. Riparian shading mitigates stream eutrophication in agricultural catchments. Freshwater Science, 33: 73-84. DOI:10.1086/674180

CABRA-RIVAS, I., A. ALONSO \& P. CASTRODÍEZ. 2014. Does stream structure affect dispersal by water? A case study of the invasive tree Ailanthus altissima in Spain. Management of Biological Invasions, 5: 179-186. Management of Biological Invasions (2014) Volume 5, Issue 2: 179-186. DOI:10.3391/mbi.2014.5.2.11

CADOTTE, M.W., K. CARSCADDEN \& N. MIROTCHNICK. 2011. Beyond species: functional diversity and the maintenance of ecological processes and services. Journal of Applied Ecology, 48: 10791087. DOI:10.1111/j.1365-2664.2011.02048.x

CALLAWAY, R.M. \& W.M. RIDENOUR. 2004. Novel weapons: invasive success and the evolution of increased competitive ability. Frontiers in Ecology and the Environment, 2: 436-443. DOI:10.18 90/1540-9295(2004)002[0436:NWISAT]2.0.CO;2

CAMPOS, J.A. \& M. HERRERA. 2009. Diagnosis de la flora alótona invasora de la CAPV. Dirección de Biodiversidad y Participación Ambiental. Departamento de Medio Ambiente y Ordenación del Territorio. Gobierno Vasco. Bilbao.

CASTRO-DÍEZ, P., N. GONZÁLEZ-MUÑOZ, A. ALONSO, A. GALLARDO \& L. POORTER. 2009. Effects of exotic invasive trees on nitrogen cycling: a case study in Central Spain. Biological Invasions, 11: 1973-1986. DOI:10.1007/s10530-00 8-9374-3

CASTRO-DÍEZ, P., N. FIERRO-BRUNNENMEISTER, N. GONZÁLEZ-MUÑOZ \& A. GALLAR- 
DO. 2012. Effects of exotic and native tree leaf litter on soil properties of two contrasting sites in the Iberian Peninsula. Plant and Soil, 350: 179-191. DOI:10.1007/s11104-011-0893-9

CASTRO-DÍEZ, P., O. GODOY, A. ALONSO, A. GALLARDO \& A. SALDAÑA. 2014. What explains variation in the impacts of exotic plant invasions on the nitrogen cycle? A meta-analysis. Ecology Letters, 17: 1-12. DOI:10.1111/ele.12197

CASTRO-DÍEZ, P., A. PAUCHARD, A. TRAVESET \& M. VILÀ. 2016. Linking the impacts of plant invasion on community functional structure and ecosystemproperties. Journal of Vegetation Science, 27: 1233-1242. DOI:10.1111/jvs.12429

CATFORD, J.A., R. JANSSON \& C. NILSSON. 2009. Reducing redundancy in invasion ecology by integrating hypotheses into a single theoretical framework. Diversity and Distributions, 15: 2240. DOI:10.1111/j.1472-4642.2008.00521.x

CATFORD, J.A., B.J. DOWNES, C.J. GIPPEL \& P.A. VESK. 2011. Flow regulation reduces native plant cover and facilitates exotic invasion in riparian wetlands. Journal of Applied Ecology, 48: 432-442. DOI: 10.1111/j.1365-2664.2010.01945.x

CATFORD, J.A., C.C. DAEHLER, H.T. MURPHY, A.W. SHEPPARD, B.D. HARDESTY, D.A. WESTCOTT, M. REJMANEK, P.J. BELLINGHAM, J. PERGL, C.C. HORVITZ \& P.E. HULME. 2012. The intermediate disturbance hypothesis and plant invasions: Implications for species richness and management. Perspectives in Plant Ecology Evolution and Systematics, 14: 231-241. DOI:10.1016/j.ppees.2011.12.002

COLAUTTI, R.I., I.A. GRIGOROVICH \& H.J. MACISAAC. 2006. Propagule pressure: A null model for biological invasions. Biological Invasions, 8: 1023-1037. DOI:10.1007/s10530-005-3735-y

CONSTAN-NAVA, S., S. SOLIVERES, R. TORICES, L. SERRA \& A. BONET. 2015. Direct and indirect effects of invasion by the alien tree Ailanthus altissima on riparian plant communities and ecosystem multifunctionality. Biological Invasions, 17: 1095-1108. DOI:10.1007/s10530-014-0780-4

COOPER, S.D., P.S. LAKE, S. SABATER, J.M. MELACK \& J.L. SABO. 2013. The effects of land use changes on streams and rivers in mediterranean climates. Hydrobiologia, 719: 383-425. DOI: 10.1007/s10750-012-1333-4

CORBIN, J.D. \& C.M. D'ANTONIO. 2011. Abundance and productivity mediate invader effects on nitrogen dynamics in a California grassland. Ecosphere, 2: art32. DOI:10.1890/ES10-00113.1

CORREA-ARANEDA, F., L. BOYERO, R. FIGUEROA, C. SANCHEZ, R. ABDALA, A. RUIZ-GARCÍA \& M. A. S. GRAÇA. 2015. Joint effects of climate warming and exotic litter (Eucalyptus globulus Labill.) on stream detritivore fitness and litter breakdown. Aquatic Sciences, 77: 197-205. DOI: 10.1007/s00027-014-0379-y

CHARLES, H. \& J.S. DUKES. 2007. Impacts of invasive species on ecosystem services. In: Biological Invasions. Nentwig, W. (ed.): 217-237. Springer-Verlag, Berlin-Heidelberg.

CHAUVET, E., E. FABRE, A. ELOSEGUI \& J. POZO. 1997. The impact of eucalypt on the leaf-associated aquatic hyphomycetes in Spanish streams. Canadian Journal of Botany-Revue Canadienne De Botanique, 75: 880-887.

CHYTRÝ, M., L. C. MASKELL, J. PINO, P. PYŠEK, M. VILÀ, X. FONT \& S.S.M. 2008. Habitat invasions by alien plants: a quantitative comparison between Mediterranean, subcontinental and oceanic regions of Europe. Journal of Applied Ecology, 45: 448-458. DOI:10.1111/j.1365-2664.2007.01398.x DANA SÁNCHEZ, E.D., M. SANZ ELORZA, S. VIVAS \& E. SOBRINO VESPERINAS. 2005. Especies vegetales invasoras en Andalucía. Dirección General de la Red de Espacios Naturales Protegidos y Servicios Ambientales. Consejería de Medio Ambiente. Junta de Andalucía.

DARWIN, C. 1859. On the origin of species by means of natural selection, or the preservation of favoured races in the struggle for life. John Murray, London.

DAVIS, M.A., J.P. GRIME \& K. THOMPSON. 2000. Fluctuating resources in plant communities: a general theory of invasibility. Journal of Ecology, 88: 528-534. DOI:10.1046/j.1365-2745.2000.00473.x

DI TOMASO, J.M. 1998. Impact, biology, and ecology of saltcedar (Tamarix spp.) in the southwestern United States. Weed Technology, 12: 326-336.

DYDERSKI, M.K., A.K. GDULA \& A.M. JAGODZINSKI. 2015. "The rich get richer" concept in riparian woody species - A case study of the Warta River Valley (Poznan, Poland). Urban Forestry \& Urban Greening, 14: 107-114. DOI:10.1016/j.ufu g.2014.12.003

EHRENFELD, J.G. 2010. Ecosystem consequences of biological invasions. Annual Review of Ecology Evolution and Systematics, 41: 59-80. DOI:10.114 6/annurev-ecolsys-102209-144650 
EMELKO, M.B., M. STONE, U. SILINS, D. ALLIN, A. L. COLLINS, C.H.S. WILLIAMS, A.M. MARTENS \& K.D. BLADON. 2016. Sediment-phosphorus dynamics can shift aquatic ecology and cause downstream legacy effects after wildfire in large river systems. Global Change Biology, 22: 11681184. DOI:10.1111/gcb. 13073

FERREIRA, V., A. LARRANAGA, V. GULIS, A. BASAGUREN, A. ELOSEGI, M.A.S. GRAÇA \& J. POZO. 2015. The effects of eucalypt plantations on plant litter decomposition and macroinvertebrate communities in Iberian streams. Forest Ecology and Management, 335: 129-138. DOI:10.101 6/j.foreco.2014.09.013

FERREIRA, V., J. KORICHEVA, J. POZO \& M.A.S. GRAÇA. 2016. A meta-analysis on the effects of changes in the composition of native forests on litter decomposition in streams. Forest Ecology and Management, 364: 27-38. DOI:10.1016/j.foreco. 2016.01.002

GEILEN, N., H. JOCHEMS, L. KREBS, S. MULLER, B. PEDROLI, T. VAN DER SLUIS, K. VAN LOOY \& S. VAN ROOIJ. 2004. Integration of ecological aspects in flood protection strategies: Defining an ecological minimum. River Research and Applications, 20: 269-283. DOI:10.1002/rra.777

GLENN, E.P. \& P.L. NAGLER. 2005. Comparative ecophysiology of Tamarix ramosissima and native trees in western U.S. riparian zones. Journal of Arid Environments, 61: 419-446. DOI:10.1016/ j.jaridenv.2004.09.025

GOUDIE, A.S. 2004. Encyclopedia of Geomorphology. Routledge, New York.

GRAF, W.L. 1978. Fluvial adjustments to spread of tamarisk in Colorado Plateau region. Geological Society of America Bulletin, 89: 1491-1501. DOI:10. 1130/0016-7606(1978)89<1491:FATTSO>2.0. $\mathrm{CO} ; 2$

GUERRERO-CAMPO, J. \& M. JARNE BRETONES. 2014. Las especies exóticas invasoras en Aragón. Consejo de Protección de la Naturaleza de Aragón, Zaragoza.

GUTIÉRREZ-LÓPEZ, M., E. RANERA, M. NOVO, R. FERNÁNDEZ \& D. TRIGO. 2014. Does the invasion of the exotic tree Ailanthus altissima affect the soil arthropod community? The case of a riparian forest of the Henares River (Madrid). European Journal of Soil Biology, 62: 39-48. DOI:10. 1016/j.ejsobi.2014.02.010

HIERRO, J.L., J.L. MARON \&R. M. CALLAWAY. 2005. A biogeographical approach to plant inva- sions: the importance of studying exotics in their introduced and native range. Journal of Ecology, 93: 5-15. DOI:10.1111/j.1365-2745.2004.00953.x

HOOD, W.G. \& R.J. NAIMAN. 2000. Vulnerability of riparian zones to invasion by exotic vascular plants. Plant Ecology, 148: 105-114. DOI:10.1023 /A:1009800327334

HULME, P.E. 2012. Weed risk assessment: a way forward or a waste of time? Journal of Applied Ecology, 49: 10-19. DOI:10.1111/j.1365-2664.2011. 02069. $\mathrm{x}$

HULME, P.E., M. VILÀ \& G. RUIZ. (eds.). 2017. Impact of Biological Invasions on Ecosystem Services. Springer. DOI:10.1007/978-3-319-45121-3

HUNTER, W.C., R.D. OHMART \& B.W. ANDERSON. 1988. Use of exotic saltcedar (Tamarix chinensis) by birds in arid riparian systems. Condor, 90: 113-123. DOI:10.2307/1368440

KARR, J.R. \& I.J. SCHLOSSER. 1978. Water-resources and land-water interface. Science, 201: 229 234. DOI:10.1126/science.201.4352.229

KEANE, R.M. \& M.J. CRAWLEY. 2002. Exotic plant invasions and the enemy release hypothesis. Trends in Ecology and Evolution, 17: 164-170. DOI:10.1016/S0169-5347(02)02499-0

KOWARIK, I. \& I. SAUMEL. 2008. Water dispersal as an additional pathway to invasions by the primarily wind-dispersed tree Ailanthus altissima. Plant Ecology, 198: 241-252. DOI:10.1007/s1125 8-008-9398-X

LAPIEDRA, O., D. SOL, A. TRAVESET \& M. VILÀ. 2015. Random processes and phylogenetic loss caused by plant invasions. Global Ecology and Biogeography, 24: 774-785. DOI:10.1111/ge b. 12310

LE MAITRE, D.C., B.W. VAN WILGEN, R.A. CHAPMAN \& D.H. MCKELLY. 1996. Invasive plants and water resources in the Western Cape province, South Africa: modeling the consequences of a lack of management. Journal of Applied Ecology, 33: 161-172.

LESLIE, A.J. \& J.R. SPOTILA. 2001. Alien plant threatens Nile crocodile (Crocodylus niloticus) breeding in Lake St. Lucia, South Africa. Biological Conservation, 98: 347-355. DOI:10.1016/S00 06-3207(00)00177-4

LEUNG, B., N. ROURA-PASCUAL, S. BACHER, J. HEIKKILA, L. BROTONS, M.A. BURGMAN, K. DEHNEN-SCHMUTZ, F. ESSL, P.E. HULME, D.M. RICHARDSON, D. SOL \& M. VILÀ. 2012. TEASIng apart alien species risk assessments: a 
framework for best practices. Ecology Letters, 15: 1475-1493. DOI:10.1111/ele.12003

LEUNG, B., N. ROURA-PASCUAL, S. BACHER, J. HEIKKILÄ, L. BROTONS , M.A. BURGMAN, K. DEHNEN-SCHMUTZ, F. ESSL, P.E. HULME, D.M. RICHARDSON, D. SOL \& M. VILÀ. 2014. Addressing a critique of the TEASI framework for invasive species risk assessment. Ecology Letters. DOI:10.1111/ele.12172

LEVINE, J.M., M. VILÀ, C.M. D'ANTONIO, J.S. DUKES, K. GRIGULIS \& S. LAVOREL. 2003. Mechanisms underlying the impacts of exotic plant invasions. Proceedings of the Royal Society of London Series B-Biological Sciences, 270: 775-781. DOI:10.1098/rspb.2003.2327

LEVINE, J.M., P.B. ADLER \& S.G. YELENIK. 2004. A meta-analysis of biotic resistance to exotic plant invasions. Ecology Letters, 7: 975-989. DOI:10.1111/j.1461-0248.2004.00657.x

LIENDO, D., I. BIURRUN, J.A. CAMPOS, M. HERRERA, J. LOIDI \& I. GARCIA-MIJANGOS 2015. Invasion patterns in riparian habitats: The role of anthropogenic pressure in temperate streams. Plant Biosystems, 149: 289-297. DOI:10.1080/11 263504.2013.822434

LOBERA, G., P. BESNE, D. VERICAT, J.A. LÓPEZTARAZON, A. TENA, I. ARISTI, J.R. DÍEZ, A. IBISATE, A. LARRANAGA, A. ELOSEGI \& R.J. BATALLA. 2015. Geomorphic status of regulated rivers in the Iberian Peninsula. Science of The Total Environment, 508: 101-114. DOI:10.1016/j.sci totenv.2014.10.058

LONSDALE, W.M. 1999. Global patterns of plant invasions and the concept of invasibility. Ecology, 80: 1522-1536. DOI:10.1890/0012-9658(1999)08 0[1522:GPOPIA]2.0.CO;2

LOWE, S.J., M. BROWNE \& S. BOUDJELAS. 2000. 100 of the World's Worst Invasive Alien Species. IUCN/SSC Invasive Species Specialist Group (ISSG), Auckland, New Zealand.

MACEDA-VEIGA, A. 2013. Towards the conservation of freshwater fish: Iberian Rivers as an example of threats and management practices. Reviews in Fish Biology and Fisheries, 23: 1-22. DOI:10. 1007/s11160-012-9275-5

MACEDA-VEIGA, A., H. BASAS, G. LANZACO, M. SALA, A. DE SOSTOA \& A. SERRA. 2016. Impacts of the invader giant reed (Arundo donax) on riparian habitats and ground arthropod communities. Biological Invasions, 18: 731-749. DOI:10. 1007/s10530-015-1044-7
MANNERS, R.B., J.C. SCHMIDT \& M.L. SCOTT. 2014. Mechanisms of vegetation-induced channel narrowing of an unregulated canyon river: Results from a natural field-scale experiment. Geomorphology, 211: 100-115. DOI:10.1016/j.geomorph. 2013.12.033

MARTÍNEZ, A., A. LARRANAGA, J. PEREZ, A. BASAGUREN \& J. POZO. 2013. Leaf-litter quality effects on stream ecosystem functioning: a comparison among five species. Fundamental and Applied Limnology, 183: 239-248. DOI:10.1127/ 1863-9135/2013/0514

MEDINA-VILLAR, S., A. ALONSO, B.R. V. DE ALDANA, E. PEREZ-CORONA \& P. CASTRODÍEZ. 2015. Decomposition and biological colonization of native and exotic leaf litter in a Central Spain stream. Limnetica, 34: 293-309.

MEDINA-VILLAR, S., S. RODRÍGUEZ-ECHEVERRÍA, P. LORENZO, A. ALONSO, E. PÉREZCORONA \& P. CASTRO-DÍEZ. 2016. Impacts of the alien trees Ailanthus altissima (Mill.) Swingle and Robinia pseudoacacia L. on soil nutrients and microbial communities. Soil Biology \& Biochemistry, 96: 65-73. DOI:10.1016/j.soilbio.2016.01.015

MELBOURNE, B.A., H.V. CORNELL, K.F. DAVIES, C.J. DUGAW, S. ELMENDORF, A.L. FREESTONE, R.J. HALL, S. HARRISON, A. HASTINGS, M. HOLLAND, M. HOLYOAK, J. LAMBRINOS, K. MOORE \& H. YOKOMIZO. 2007. Invasion in a heterogeneous world: resistance, coexistence or hostile takeover? Ecology Letters, 10: 77-94. DOI:10.1111/j.1461-0248.2006.00987.x

MENENDEZ, M., E. DESCALS, T. RIERA \& O. MOYA. 2013. Do non-native Platanus hybrida riparian plantations affect leaf litter decomposition in streams? Hydrobiologia, 716: 5-20. DOI:10.10 07/s10750-013-1539-0

MERRITT, D.M. \& N.L. POFF. 2010. Shifting dominance of riparian Populus and Tamarix along gradients of flow alteration in western North American rivers. Ecological Applications, 20: 135-152. DOI:10.1890/08-2251.1

MERRITT, D.M. \& P.B. SHAFROTH. 2012. Edaphic, salinity, and stand structural trends in chronosequences of native and non-native dominated riparian forests along the Colorado River, USA. Biological Invasions, 14: 2665-2685. DOI:10.100 7/s10530-012-0263-4

MITRAKOS, K.A. 1980. A theory for Mediterranean plant life. Acta Oecologica, 1: 245-252. 
NAGLER, P.L., O. HINOJOSA-HUERTA, E.P. GLENN, J. GARCÍA-HERNANDEZ, R. ROMO, C. CURTIS, A.R. HUETE \& S.G. NELSON. 2005. Regeneration of native trees in the presence of invasive saltcedar in the Colorado River delta, Mexico. Conservation Biology, 19: 1842-1852. DOI:10. 1111/j.1523-1739.2005.00234.x

NAIMAN, R.J. \& H. DECAMPS. 1997. The ecology of interfaces: Riparian zones. Annual Review of Ecology and Systematics, 28: 621-658. DOI:10.1146/ annurev.ecolsys.28.1.621

OLIVEIRA, J.M., F. FERNANDES \& M.T. FERREIRA. 2016. Effects of forest management on physical habitats and fish assemblages in Iberian eucalypt streams. Forest Ecology and Management, 363: 1-10. DOI:10.1016/j.foreco.2015.12.011

OSTERKAMP, W.R. \& C.R. HUPP. 2010. Fluvial processes and vegetation-Glimpses of the past, the present, and perhaps the future. Geomorphology, 116: 274-285. DOI:10.1016/j.geomorph.2009.11. 018

PINTO, C., J.P. SOUSA, M.A.S. GRAÇA \& M.M. DA GAMA. 1997. Forest Soil Collembola. Do tree introductions make a difference? Pedobiologia, 41: 131-138.

PYŠEK, P., V. JAROŠIK, P.E. HULME, J. PERGL, M. HEJDA, U. SCHAFFNER \& M. VILÀ. 2012. A global assessment of invasive plant impacts on resident species, communities and ecosystems: the interaction of impact measures, invading species' traits and environment. Global Change Biology, 18: 1725-1737. DOI:10.1111/j.1365-2486.2011. 02636.x

REAL DECRETO. 630/2013 de 2 de agosto, por el que se regula el Catálogo español de especies exóticas invasoras.

REJMÁNEK, M. \& D.M. RICHARDSON. 1996. What attributes make some plant species more invasive? Ecology, 77: 1655-1661. DOI:10.2307/22 65768

RICHARDSON, D.M., P. PYŠEK, M. REJMÁNEK, M.G. BARBOUR, F.D. PANETTA \& C.J. WEST. 2000. Naturalization and invasion of alien plants: concepts and definitions. Diversity and Distributions, 6: 93-107. DOI:10.1046/j.1472-4642.2000. 00083.x

RICHARDSON, D.M. \& B.W. VAN WILGEN. 2004. Invasive alien plants in South Africa: how well do we understand the ecological impacts? South African Journal of Science, 100: 45-52.
RUNDEL, P.W., I.A. DICKIE \& D.M. RICHARDSON. 2014. Tree invasions into treeless areas: mechanisms and ecosystem processes. Biological Invasions, 16: 663-675. DOI:10.1007/s10530-0130614-9

SANZ ELORZA, M., E.D. DANA SÁNCHEZ \& E. SOBRINO VESPERINAS. 2004. Atlas de las plantas alóctonas invasoras en España. Dirección General para la Biodiversidad. Ministerio de Medio Ambiente, Madrid.

SHACKLETON, R.T., D.C. LE MAITRE, B.W. VAN WILGEN \& D.M. RICHARDSON. 2015. The impact of invasive alien Prosopis species (mesquite) on native plants in different environments in South Africa. South African Journal of Botany, 97: 2531. DOI:10.1016/j.sajb.2014.12.008

SHAFROTH, P.B., J.R. CLEVERLY, T.L. DUDLEY, J.P. TAYLOR, C. VAN RIPER, E.P. WEEKS \& J.N. STUART. 2005. Control of Tamarix in the Western United States: Implications for water salvage, wildlife use, and riparian restoration. Environmental Management, 35: 231-246. DOI:10.10 07/s00267-004-0099-5

SHAKESBY, R.A. 2011. Post-wildfire soil erosion in the Mediterranean: Review and future research directions. Earth-Science Reviews, 105: 71-100. DOI: 10.1016/j.earscirev.2011.01.001

SIMBERLOFF, D. 2009. We can eliminate invasions or live with them. Successful management projects. Biological Invasions, 11: 149-157. DOI:10. 1007/s10530-008-9317-z

TABACCHI, E., A.M. PLANTY-TABACCHI, L. ROQUES \& E. NADAL. 2005. Seed inputs in riparian zones: Implications for plant invasion. $R i$ ver Research and Applications, 21: 299-313. DOI: 10.1002/rra.848

TICKNER, D.P., P.G. ANGOLD, A.M. GURNELL \& J.O. MOUNTFORD. 2001. Riparian plant invasions: hydrogeomorphological control and ecological impacts. Progress in Physical Geography, 25: 22-52. DOI:10.1191/030913301673178792

TOMBOLINI, I., G. CANEVA, L. CANCELLIERI, S. ABATI \& S. CESCHIN. 2014. Damming effects on upstream riparian and aquatic vegetation: the case study of Nazzano (Tiber River, central Italy). Knowledge and Management of Aquatic Ecosystems:15. DOI:10.1051/kmae/2013085

VIDAL-ABARCA GUTIÉRREZ, M.R. \& M.L.S. ALONSO. 2013. Which are, what is their status and what can we expect from ecosystem services 
provided by Spanish rivers and riparian areas? Biodiversity and Conservation, 22: 2469-2503. DOI: 10.1007/s10531-013-0532-2

VILÀ, M., E. GARCÍA-BERTHOU, D. SOL \& J. PINO. 2001. Survey of the naturalized plants and vertebrates in peninsular Spain. Ecologia Mediterranea, 27: 55-67.

VILÀ, M., C. BASNOU, P. PYŠEK, M. JOSEFSSON, P. GENOVESI, S. GOLLASCH, W. NENTWIG, S. OLENIN, A. ROQUES, D. ROY, P. E. HULME, P. ANDRIOPOULOS, M. ARIANOUTSOU, S. AUGUSTIN, S. BACHER, I. BAZOS, F. BRETAGNOLLE, F. CHIRON, P. CLERGEAU, P.O. COCHARD, C. COCQUEMPOT, A. COEUR DACIER, M. DAVID, P. DELIPETROU, M.L. DESPREZ-LOUSTAU, V. DIDZIULIS, F. DORKELD, F. ESSL, B. S. GALIL, J. GASQUEZ, K. GEORGHIOU, M. HEJDA, V. JAROŠIK, S. KARK, I. KOKKORIS, I. KUHN, P.W. LAMBDON, C. LÓPEZ-VAAMONDE, A. MARCER, A. MIGEON, M. MCLOUGHLIN, D. MINCHIN, M. NAVAJAS, V. E. PANOV, M. PASCAL, J. PERGL, I. PERGLOVA, J. PINO, K. POBOLJSAJ, W. RABITSCH, J.Y. RASPLUS, D. SAUVARD, R. SCALERA, O. SEDLACEK, S. SHIRLEY, M. WINTER, A. YANNITSAROS, A. YART, P. ZAGATTI \& A. ZIKOS. 2010. How well do we understand the impacts of alien species on ecosys- tem services? A pan-European, cross-taxa assessment. Frontiers in Ecology and the Environment, 8: 135-144. DOI:10.1890/080083

VILÀ, M., J.L. ESPINAR, M. HEJDA, P.E. HULME, V. JAROŠIK, J.L. MARON, J. PERGL, U. SCHAFFNER, Y. SUN \& P. PYŠEK. 2011. Ecological impacts of invasive alien plants: a meta-analysis of their effects on species, communities and ecosystems. Ecology Letters, 14: 702-708.

VILÀ, M., R.P. ROHR, J.L. ESPINAR, P.E. HULME, J. PERGL, J.J. LE ROUX, U. SCHAFFNER \& P. PYŠEK. 2015. Explaining the variation in impacts of non-native plants on local-scale species richness: the role of phylogenetic relatedness. Global Ecology and Biogeography, 24: 139-146. DOI:10. 1111/geb.12249

WILLIAMSON, M. \& A. FITTER. 1996. The varying success of invaders. Ecology, 77: 1661-1666. DOI: $10.2307 / 2265769$

ZARFL, C., A.E. LUMSDON, J. BERLEKAMP, L. TYDECKS \& K. TOCKNER. 2015. A global boom in hydropower dam construction. Aquatic Sciences, 77: 161-170. DOI:10.1007/s00027-0140377-0

ZAVALETA, E. 2000. The economic value of controlling an invasive shrub. Ambio, 29: 462-467. DOI: 10.1639/0044-7447(2000)029[0462:TEVOCA]2.0. $\mathrm{CO} ; 2$

Con la colaboración de:

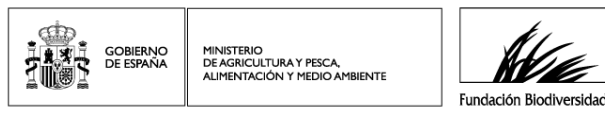

